\title{
Insulin-Like Growth Factors-1 Receptor (IGF-1R) Expression and the Phosphorylation of Endogenous Substrates Lead to Maturation of the Pacific oyster, Crassostrea gigas
}

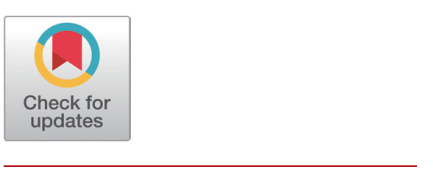

Received: February 6, 2021

Revised: February 15, 2021

Accepted: February 26, 2021

${ }^{\dagger}$ Corresponding author

Youn Hee Choi

Department of Marine Bio-Materials \&

Aquaculture, Pukyong National University,

Busan 48513, Korea

Tel: +82-51-629-5915

Fax: +82-51-629-5908

E-mail: unichoi@pknu.ac.kr

Copyright $\odot 2021$ The Korean Society of Developmental Biology.

This is an Open Access article distributed under the terms of the Creative Commons Attribution Non-Commercial License (http://creativecommons.org/licenses/ by-nc/4.0/) which permits unrestricted non-commercial use, distribution, and reproduction in any medium, provided the original work is properly cited.

ORCID

Youn Hee Choi

https://orcid.org/0000-0002-0091-7893 Su-Jin Park

https://orcid.org/0000-0002-8820-2541

Conflict of interests

The authors declare no potential conflict of interest.

\section{Acknowledgements}

The authors thank Southeast Sea Fisheries Institute, National Institute of Fisheries Science, Namhae, Korea, for access to Pacific oyster. This research was supported by the Basic Science Research Program through the National Research Foundation of Korea (NRF) funded by the Ministry of Education (NRF- 2020R1F1A1074614).

\author{
Su-Jin Park' and ${ }^{\dagger}$ Youn Hee Choi ${ }^{1,2}$ \\ 'Dept. of Fisheries Biology, Pukyong National University, Busan 48513, Korea \\ ${ }^{2}$ Dept. of Marine Bio-Materials \& Aquaculture, Pukyong National University, Busan 48513, Korea
}

\section{Abstract}

This study investigated the IGF-1 signal in specific tissues using Pacific oysters artificially matured via water temperature elevation. Pacific oysters were subjected to water temperature elevation from March to June, and 20 were randomly sampled each month. The condition index $(\mathrm{Cl})$ and tissue weight rate (TWR) were examined by measuring shell length, shell height, shell width, and soft tissue weight. The IGF-1 signal in tissues (adductor muscle, digestive glands, gills, labial palps, mantle edges, and gonads) was analyzed by sulfate-polyacrylamide gel electrophoresis (SDS-PAGE) and Western blotting. From April to June, the TWR of females and males increased from $19.1 \pm 2.9$ to $21.0 \pm 3.6$ and $18.2 \pm 2.0$ to $19.2 \pm 2.5$, respectively, while the $\mathrm{Cl}$ remained the same. The IGF-1 signal in each tissue differed. IGF-1 was expressed in the adductor muscle, while tyrosine was expressed in all tissues. The phosphor (p)-ERK and $\mathrm{p}$-AKT activities were high in the adductor muscle, mantle edge, and gonads. IGF-1 signaling affected the growth and maturity of the Pacific oysters examined.

Keywords: Pacific oyster, Condition index, Tissue weight rate, Insulin-like growth factors-1 (IGF-1) signal

\section{INTRODUCTION}

In 2020, aquaculture in Korea yielded 325,889 tons of oysters (Korean Statistical Information Service, Ministry of Oceans and Fisheries, 2020). The main production site is the south coast, while some varieties are cultivated via various methods on the west coast (Hwang et al., 2016). However, the seedlings needed for oyster farming in Korea are dependent on natural culture. When there are few natural seedlings, it is difficult to secure a stable seed supply. Since the 1970s, the pollution of coastal waters, aging of fish farms, and deterioration of fishing conditions have led to seed shortages. In 1992, a major seed-collecting area on the southern coast was severely damaged (Park et al., 1999). Currently, artificial seed production is actively conducted to ensure a stable supply to meet the demand for oysters. The quality of the mother oysters affects seedling growth (Lee et al., 2008; Kim et al., 2013). Although 
Authors' contributions

Conceptualization: $\mathrm{Choi} Y \mathrm{H}$.

Data curation: Park SJ, Choi YH

Formal analysis: Park SJ, Choi YH.

Methodology: Choi YH.

Investigation: Park SJ, Choi YH.

Writing-original draft: Park SJ, Choi YH.

Writing-review \& editing: Park SJ, Choi YH.

\section{Ethics approval}

This article does not require IRB/IACUC approval

because there are no human and animal participants. studies have evaluated mother oysters by examining changes in body components (Lim et al., 2011; Kim et al., 2014), a few studies have evaluated endogenous factors, such as the expression of insulin-like growth factors (IGFs), in mother oysters. The IGF system regulates somatic growth and development in fish, as in mammals (Duan, 1997; Le Bail et al., 1998; Moriyama et al., 2000). IGF-1 is an anabolic hormone that regulates development, somatic and skeletal muscle growth, and reproduction via endocrine, autocrine, and paracrine mechanisms mediated by growth hormone (Duan, 1997; Liu et al., 2017).

Here, we examined IGF-1 receptor (IGF-1R) expression and the phosphorylation of endogenous substrates in the IGF-1 pathway to evaluate the growth and maturity of artificially matured female and male Pacific oysters.

\section{MATERIALS AND METHODS}

\section{Sample collection and preparation}

Broodstock of artificially matured Pacific oysters, C. gigas, was obtained from the Southeast Sea Fisheries Institute, National Institute of Fisheries Science, Namhae, Korea. Each month from March to June 2016, 80 C. gigas were obtained. These were reared in running water at a flow rate of $15 \mathrm{~L} / \mathrm{min}$ and fed a mixture of $10-15 \times 10^{4}$ cells $/ \mathrm{mL}$ Isochrysis galbana, Pheodactylum sp., Tetraselmis sp., and Chlorella sp. The water temperature was raised slowly from $14.5^{\circ} \mathrm{C}$ to $22.5^{\circ} \mathrm{C}$ over 15 days and then kept at $22.5 \pm 0.34^{\circ} \mathrm{C}$ until the end of the study. The salinity was $32.2-33.8 \mathrm{psu}$.

The oyster shell length (SL), shell height (SH), and shell width (SW) were measured using Vernier calipers; total wet weight and soft tissue weight (STW) were measured using an electronic balance. The condition index (CI) and tissue weight rate (TWR) were calculated according to Choi \& Chang (2003) using the following equations:

$\mathrm{CI}=\mathrm{STW}(\mathrm{g}) / \mathrm{SL}(\mathrm{mm}) \times \mathrm{SH}(\mathrm{mm}) \times \mathrm{SW}(\mathrm{mm}) \times 1,000$

TWR $=$ STW $(\mathrm{g}) /$ Total wet weight $(\mathrm{g}) \times 100$

The adductor muscle, digestive gland, gills, labial palps, mantle edge, and gonads were isolated, and $0.5 \mathrm{~g}$ of each was frozen in liquid nitrogen and stored at $-80^{\circ} \mathrm{C}$.

\section{Western blot analysis}

The tissues were homogenized in RIPA lysis buffer (50 mM Tris, $1 \mathrm{mM}$ EGTA, $150 \mathrm{mM}$ $\mathrm{NaCl}, 1 \% \mathrm{NP}-40$, and $0.25 \%$ sodium deoxycholate) containing protease inhibitors $(1 \mu \mathrm{g} / \mathrm{mL}$ aprotinin, $1 \mu \mathrm{g} / \mathrm{mL}$ leupeptin, $1 \mu \mathrm{g} / \mathrm{mL}$ pepstatin, $1 \mathrm{mM} \mathrm{Na} \mathrm{VO}_{4}, 1 \mathrm{mM} \mathrm{NaF}$, and $1 \mathrm{mM}$ PMSF). Samples were centrifuged at $14,483 \times \mathrm{g}$ for $10 \mathrm{~min}$, and the supernatant was collected. The protein concentration was measured using a BCA protein assay kit (Pierce Biotechnology, Rockford, IL, USA). Proteins $(35-50 \mu \mathrm{g})$ were separated on $8 \%-10 \%$ polyacrylamide gels by sodium dodecyl sulfate-polyacrylamide gel electrophoresis (SDS-PAGE) and then transferred to polyvinyl difluoride membranes (Millipore). The membranes were blocked in TBS-T (10 mM Tris-HCl,

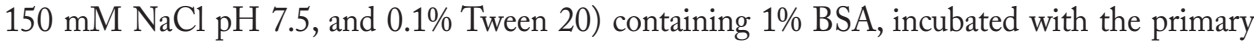
and secondary antibodies at room temperature for at least $1 \mathrm{~h}$, and then detected using enhanced chemiluminescence Western blotting reagents (Santa Cruz Biotechnology, Santa Cruz, CA, USA). Between each step, the membranes were washed twice with TBST. The following primary antibodies and an anti-mouse secondary antibody, obtained from Santa Cruz Biotechnology, were diluted 1:1,000: IGF-1, IGF-1R, phosphorylated (p)-IGF-1R (PY99), AKT, p-AKT, ERK, 
and p-ERK. Monoclonal mouse anti- $\beta$-actin antibody (Santa Cruz Biotechnology, Santa Cruz, CA, USA) was used as a control. The proteins were detected using enhanced chemiluminescence detection reagents (Advansta, Menlo Park, CA, USA) and visualized using the GeneSys imaging system (Syngene Synoptics, London, UK).

\section{Statistical analysis}

Data are presented as means \pm SD. Significant differences among means were determined by one-way analysis of variance (ANOVA) in SPSS v. 10.0 (SPSS, Chicago, IL, USA).

\section{RESULTS AND DISCUSSION}

\section{Growth and maturation of $C$. gigas}

The growth of $C$. gigas was assessed by measuring SL, SH, SW, and STW for 4 months (Fig. 1A). Beginning in April, when it is possible to distinguish males and females, the monthly $\mathrm{CI}$ and TWR were assessed (Fig. 1B). SL, SH, SW, and STW were all significantly $(p<0.05)$ lower in March when maturation induction was started. Shell growth did not differ until June, but STW increased over time (Fig. 1A). In March, it was difficult to distinguish male and female oysters. While there was no difference in shell growth from April to June, females and males had the highest CI and TWR in June, when the water temperature had been elevated the longest (Fig. 1B).

Oyster maturation depends on water temperature, which affects gamete maturation, ovulation, and spawning in many fish species and oysters (Loosanoff \& Davis, 1952; Anguis \& Canavate, 2005; De Oliveira Ramos et al., 2014). Oyster maturation can depend on temperature, even within the genus Crassostrea (Loosanoff \& Davis, 1952; De Oliveira Ramos et al., 2014). Mangrove oyster C. gasar gonadal tissue matured at $22^{\circ} \mathrm{C}$ and $26^{\circ} \mathrm{C}$, but not at $18^{\circ} \mathrm{C}$ (De Oliveira Ramos et al., 2014),

(A)

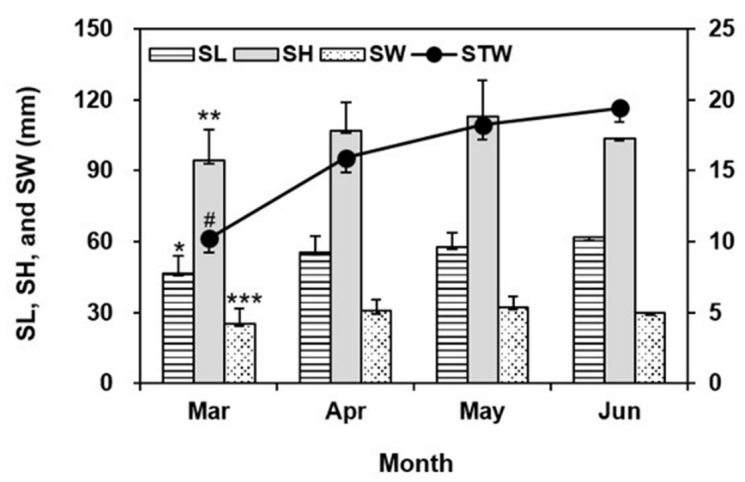

(B)

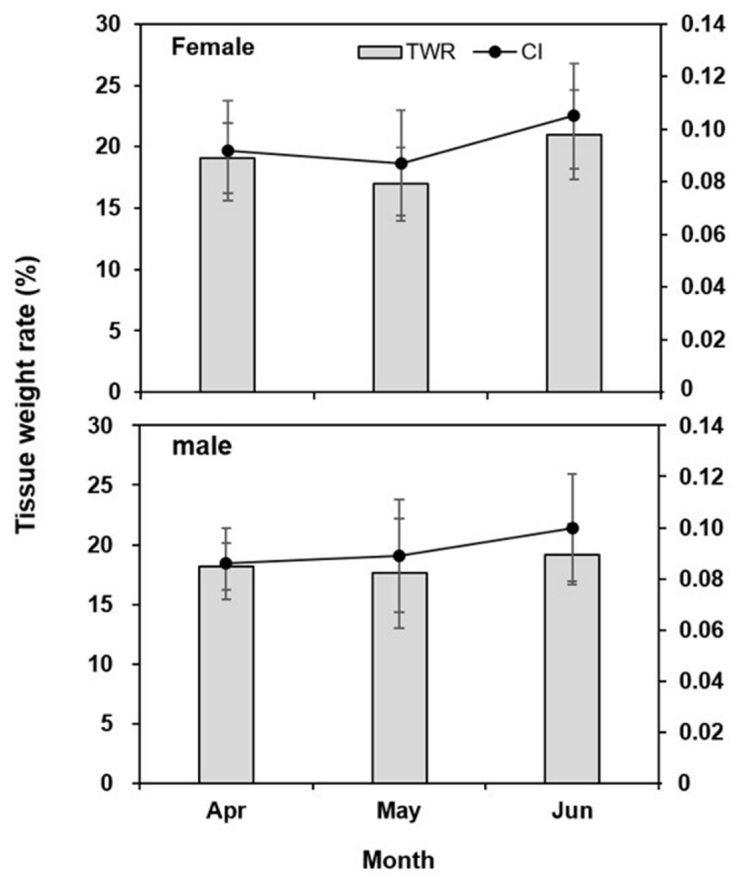

Fig. 1. The shell length (SL), shell height (SH), and shell width (SW), soft tissue weight (STW), tissue weight rate (TWR), and condition index (Cl) of the Pacific oyster, Crassostrea gigas. Values are means \pm SD. ${ }^{*, * *, * * *}$ and ${ }^{*}$ indicate significant differences at $p<0.05$. 
and the $\mathrm{CI}$ did not differ among the temperature treatments at the beginning of the experiment.

In oysters of the genus Crassostrea, an individual can be male or female depending on the environmental conditions (De Oliveira Ramos et al., 2014). In this study, the mean ratio of C. gigas females to males from April to June was 1:0.875.

\section{IGF-1R expression and the phosphorylation of endogenous substrates}

IFG-1R has two extracellular $\alpha$-subunits with ligand-binding sites. Each $\alpha$-subunit couples to one of two membrane-spanning $\beta$-subunits, which contain an intracellular domain with intrinsic tyrosine kinase activity (Adams et al., 2000). IGF-1 binding to its receptor initiates a complex signaling cascade in the cell (Foncea et al., 1997). Activation is initiated by triggering the $\beta$-subunit kinase domains, leading to receptor autophosphorylation and tyrosine phosphorylation of multiple substrates (Adams et al., 2000). IGF-1R activation may be involved in the survival of surf clam (Spisula sachalinensis) larvae (Choi \& Nam, 2014) and the growth of C. gigas (Choi et al., 2018). We investigated the expression of IGF-1R and the phosphorylation of its endogenous substrates in various tissues, including the gonads of oysters artificially matured via water temperature elevation. IGF-1R $\beta$ was detected in all female and male tissues, whereas tyrosine phosphorylation (PY99) of the intracellular $\beta$-subunits was clearly detected in females, especially the gonads ( $p<0.05$, Fig. $2 \mathrm{~A})$.

(A)
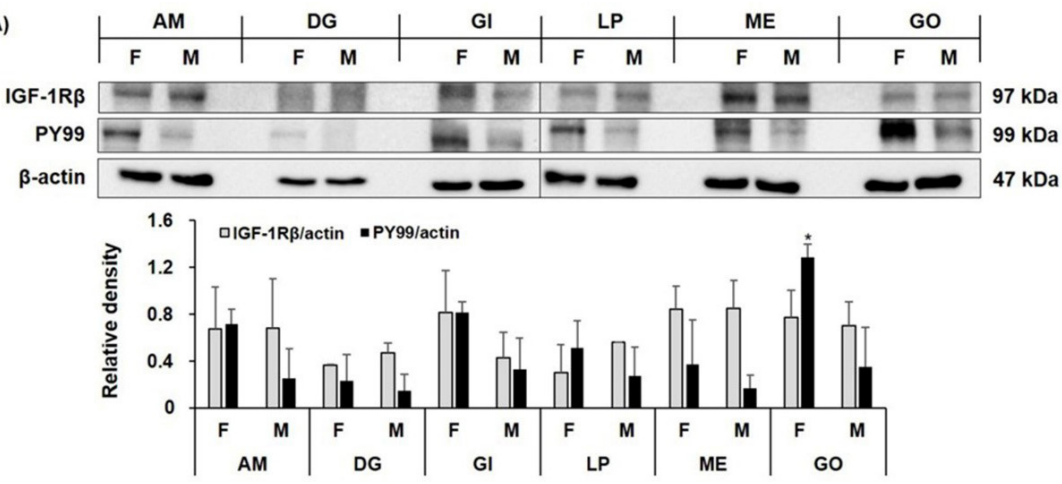

(B)

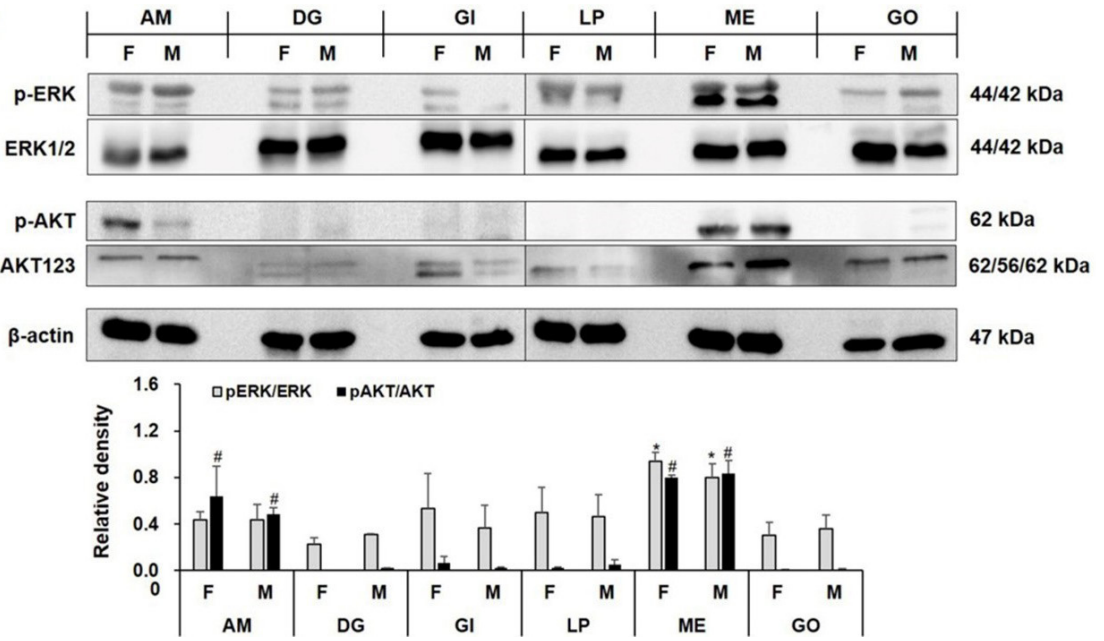

Fig. 2. Expression of the IGF-IR $\beta$-subunit, phosphorylated tyrosine residue 99 (PY99), ERK1/2, p-ERK, AKT123, and p-AKT in Pacific oyster tissues. Cell lysates were resolved by SDS-PAGE and analyzed by Western blot analysis. Values are means \pm SEM. ${ }^{*}$ and ${ }^{\#}$ indicate significant differences at $p<0.05$. AM, adductor muscle; DG, digestive gland; GI, gill; LP, labial palp; ME, mantle edge; GO, gonad; F, female; M, male; IGF, Insulin-like growth factors; SDS-PAGE, sulfate-polyacrylamide gel electrophoresis. 
There was significant $\mathrm{p}$-ERK and $\mathrm{p}$-AKT expression in the adductor muscle and mantle edge $(p<0.05$, Fig. $2 \mathrm{~B}$ ). While there were differences in the expression of endogenous substrates, the expression of downstream factors is believed to be involved in IGF signaling in artificially matured oysters. Further studies are needed to examine the association between the IGF-1 signaling pathway (PI3K and Ras/ MAPK pathways) and maturation mechanisms in shellfish.

\section{REFERENCES}

Adams TE, Epa VC, Garrett TPJ, Ward CW (2000) Structure and function of the type 1 insulinlike growth factor receptor. Cell Mol Life Sci 57:1050-1093.

Anguis MV, Canavate JP (2005) Spawning of captive Senegal sole (Solea senegalensis) under a naturally fluctuating temperature regime. Aquaculture 243:133-145.

Choi YH, Chang YJ (2003) Gametogenic cycle of the transplanted-cultured pearl oyster, Pinctada fucata martensii (Bivalvia: Pteriidae) in Korea. Aquaculture 220:781-790.

Choi YH, Nam TJ (2014) Influence of the toxicity of cryoprotective agents on the involvement of insulin-like growth factor-I receptor in surf clam (Spisula sachalinensis) larvae. Cryo Letters 35:537-543.

Choi YH, Kim EY, Nam TJ (2018) Involvement of insulin-like growth factor in intraspecific variation in growth of Pacific oyster Crassostrea gigas during winter. Fish Sci 84:1017-1024.

Duan C (1997) The insulin-like growth factor system and its biological actions in fish. Am Zool 37:491-503.

Foncea R, Andersson M, Ketterman A, Blakesley V, Sapag-Hagar M, Sugden PH, LeRoith D, Lavandero S (1997) Insulin-like growth factor-I rapidly activates multiple signal transduction pathways in cultured rat cardiac myocytes.J Biol Chem 272:19115-19124.

Hwang IJ, Han JC, Hur YB, Lim HJ (2016) Seasonal variation in the body composition, amino acid, fatty acid and glycogen contents of triploid Pacific oyster, Crassostrea gigas in western coastal waters of Korea. Korean J Malacol 32:269-277.

Kim KT, Lim HK, Chang YJ (2013) Survival rates with time course of frozen-thawed Pacific oyster larvae in indoor rearing system. Dev Reprod 17:337-343.

Kim MA, Shim KB, Par JS, Oh EG, Shi SB, Par K, Lim CW (2014) Seasonal variation in the proximate composition, $\mathrm{pH}$ and glycogen content of oysters Crassostrea gigas collected in Geoje and Jaran Bay in Korea. Korean J Fish Aquat Sci 47:713-718.

Le Bail PY, Gentil V, Noel O, Gomez JM, Carre F, Le Goff P, Weil C (1998) Structure, function, and regulation of insulin-like growth factors in fish. Ann NY Acad Sci 839:157-161.

Lee JM, Park AJ, Cho SM, Park KD (2008) Growth comparison of the Pacific oyster, Crassostrea gigas, by three different suspended time around coast of Gyeongnam. Korean J Malacol 24:109-119.

Lim HJ, Lee TS, Cho PG, Back SH, Byun SG, Choi EH (2011) The production efficiency of cupped oyster Crassostrea gigas sprat according to clutch and growth comparing diploid and triploid oysters in off-bottom culture for tidal flat utilization. Korean J Fish Aquat Sci 44:259-266.

Liu Z, Han T, Fishman S, Butler J, Zimmermann T, Tremblay F, Harbison C, Agrawal N, Kopchick JJ, Schaffler MB, Yakar S (2017) Ablation of hepatic production of the acid labile subunit in the bovine-GH transgenic mice: Effects on organ and skeletal growth. Endocrinology 158:25562571.

Loosanoff VL, Davis HC (1952) Temperature requirements for maturation of gonads of northern oysters. Biol Bull 103:80-96.

Moriyama S, Ayson FG, Kawauchi H (2000) Growth regulation by insulin-like growth factor-I in 
fish. Biosci Biotechnol Biochem 64:1553-1562.

Park MS, Lyu HY, Lee TS (1999) Investigation on the cause of bad natural seed collection of the Pacific oyster, Crassostrea gigas: Relationships between the conditions of mother shell and the viability of the released eggs and larvae based on the pathological and embryological survey. J Korean Fish Soc 32:62-67.

De Oliveira Ramos C, de Miranda Gomes CHA, Magalhães ARM, dos Santos AI, de Melo CMR (2014) Maturation of the Mangrove Oyster Crassostrea gasar at different temperatures in the laboratory. J Shell Res 33:187-194. 